\title{
Strained Compromises? Danish Flexicurity During Crisis
}

I Christian Lyhne Ibsen

PhD fellow, FAOS, University of Copenhagen, Denmark

\begin{abstract}
The Danish concept of flexicurity in a 'Golden Triangle' of low job protection, high income security and high employment security is not only about a balance between labor market flexibility and social security. Arguably, it is also a series of more or less stable underlying compromises between social partners about the main mechanisms and aims of labor market regulation which - supposedly - should be focused on employment rather than jobs, and competition on quality rather than on labor costs.

However, the 'Golden Triangle' - this article argues - seems in need of complementary concepts. The article therefore introduces, 'centralized decentralization' - a concept that directs our attention to forms of flexibility and security primarily for people in work.

Most studies on Danish flexicurity have been carried out under favorable economic conditions. In light of the economic slump hitting Denmark in 2008, this article investigates if and how the recession challenged these compromises by comparing two rounds of case-based interviews in three metalworking companies in 2007 and 2009.

It is shown that practice has indeed changed - albeit modestly - due to worsened economic circumstances. For example the case studies show that the hypothesized preference for external numerical flexibility is perhaps too crude as employers use different ways to restructure employment. Especially the examples of de facto concessionary bargaining to save jobs are important here - although the extent of concessions is modest.

The evidence thus suggests that the 'Golden Triangle' flexicurity compromises are indeed strained by the economic cycle and that responses to impetus for restructuring are far more nuanced than sometimes portrayed. It is argues that more company studies across national labor markets and industrial relations institutions will enhance our understanding of the dynamics during times of restructuring.
\end{abstract}

\section{KEY WORDS}

centralized decentralization / collective bargaining / company level / flexicurity / employment policy / restructuring

\section{Introduction}

or a time, it seemed as though there was no end to the success of the Danish flexicurity model. Most prominently, the European Commission has endorsed the concept with Denmark as a primary example of how to achieve a dynamic labor market without losing the social security elements. In connection, the Commission has published various flexicurity guidelines and principles designed to lead the way for member state reforms (Mailand 2009). 
When the financial crisis hit the Danish real economy in 2008, some scholars were, however, critical as to whether the model would only fare well during good times (e.g. Tangian 2010).

In line with van den Berg (2008) and Klindt (2008), this article argues that Danish flexicurity model is based on a few fundamental compromises between capital, labor and government that also apply to the flexicurity model. Firstly, the acceptance of job losses should be inherent in the Danish labor market as unemployment is bolstered by income security and employment security. Secondly, high wages and labor standards are kept through a coordinated system of collective bargaining and agreements at sector and company level which force companies to focus on niches of high value added production rather than on labor costs. Thirdly, trade unions take on a partnership approach to bargaining which rests on an obligation to peace in the duration of collective agreements.

However, with unemployment levels escalating during the current economic crisis there is good reason to re-visit these supposed compromises by looking at the practice of Danish social partners on the shop floor - a level often neglected in flexicurity studies. Surely, if the celebrated Danish flexicurity is to have analytical and political relevance in the future it is important that it sustains different economic circumstances. As such, the current crisis provides an "unwelcome" test-bed for the model. The article thus attempts to answer the following question: In what ways has the current economic crisis challenged the underlying compromises between social partners in the Danish flexicurity model at company level?

In order to answer this broad question, the article begins with a conceptual discussion and outlines the underlying compromises by linking flexicurity with the practice of industrial relations at company level. An additional version of Danish flexicurity is presented which point to a host of possible responses to the impetus of restructuring. Hereby the section arrives at different sets of hypotheses about the practice of management and company level shop stewards. This is followed by a presentation of the data and methods used to examine this practice. Next section examines evidence before and during the economic crisis in order to assess the robustness of compromises between social partners at company level. Has a change in practice occurred and has it fundamentally altered the compromises? Another section then summarizes and discusses findings and it is suggested that the underlying compromises inherent in the 'Golden Triangle' are indeed strained by the economic cycle and that social partners at company level are forced to respond to a crisis in various ways. This finding is taken up in the conclusion which points to the pitfalls of building concepts such as flexicurity based on limited periods of stability.

\section{Flexicurity}

It is worthwhile recalling how flexibility and security - the odd bedfellows - could be merged into the concept of flexicurity.

Flexibility can generally be defined as the ability to adjust labor activities to business activities. What we mean by ability is not the personal competences of managers but rather the possibility for adjustment. Flexibility is thus a functional term that captures the possibility of aligning the use of labor to the needs of business activities, be it production, service delivery etc. Often - but by far not exclusively - flexibility will serve managerial interests (Ibsen \& Mailand, 2009). 
Security can generally be defined as the minimization of social risks. Risk is broadly understood here as circumstances that could potentially deteriorate the well-being of individuals connected to the labor market. Security is therefore broader than flexibility in that it does not presuppose an employment relationship. Security is also a functional term that captures the possibility of reducing the probability of circumstances that deteriorate the well-being of individuals with connection to the labor market (Ibsen \& Mailand, 2009).

In the often cited matrix developed by Ton Wilthagen a distinction is made between four sub-categories of flexibility and security connected to possibilities for adjustment and minimization of risk, respectively (Wilthagen \& Tros, 2004).

External numerical flexibility refers to a company's ability to adjust the intake of labor by hiring and firing which could be hampered by restrictive employment protection legislation (EPL) stipulating social/legal obligations connected to redundancies. If regulation is permissive, this could induce companies to take on workers without concern for how they will get rid of labor in downturns. Also, the ability to take on workers on fixed or temporary contracts is noted as a way of increasing external numerical flexibility.

Working time flexibility refers to a company's ability to adjust the use of labor already working for the company. Not only does this include options for adjusting the length, variation and distribution of working time, it also refers to hiring of part timers.

Functional flexibility refers to the workers' ability to take on wide ranges of tasks and responsibilities requiring high levels of multiple skills. This should allow for job rotation, devolution of decision autonomy and thereby flatter organizational structures.

Wage flexibility refers to the company's ability to make wages variable and contingent upon different parameters such as performance (individual or collective), skill attainment or task responsibility.

Job security refers to the ability of workers to stay in the same job as expressed by job tenure and is of course closely and inversely related to external numerical flexibility.

Employment security could be said to comprise job security but also refers to the ability to find employment generally. While tied to general labor market conditions, employment security is also connected to policies that enhance employability such as active labor market policies together with in-work training and skill development.

Income security refers to protection of stable income levels during transitions in and out of employment statuses, e.g. in case of unemployment or during new job situations and job content.

Finally, combination security refers to the ability of workers to combine work with other phases of life such as parenthood, education or care-taking. This is typically called work-life balance.

Applying the matrix to Danish labor market regulation as seen in figure 1, we find that some issues are regulated through statutory provisions and public schemes, some through collective agreements and some through company level HR policies. Alongside this body of regulation, come EU-directives and agreements that have been implemented through collective agreements and additional legislation - usually without causing major controversy as Danish labor standards were already in conformity with directives.

Moreover, some forms of flexibility and some forms of security can said to be external or internal, i.e. apply to individuals moving out of jobs and to employees in jobs. The point is that different forms of securities relate to different forms of flexibility depending on the employment status of the individual. Some securities are designed to cushion the 
Figure I: External and internal versions of flexicurity

\begin{tabular}{|c|c|c|c|c|c|c|c|}
\hline & & \multicolumn{2}{|c|}{$\begin{array}{l}\text { External security provided } \\
\text { solely by public schemes }\end{array}$} & \multicolumn{4}{|c|}{$\begin{array}{l}\text { Internal security provided by collective agreements, } \\
\text { statutory regulation and HR policies }\end{array}$} \\
\hline & & Employment security & $\begin{array}{l}\text { Income } \\
\text { security }\end{array}$ & $\begin{array}{l}\text { Job } \\
\text { Security }\end{array}$ & $\begin{array}{l}\text { Employment } \\
\text { security }\end{array}$ & $\begin{array}{l}\text { Income } \\
\text { security }\end{array}$ & $\begin{array}{l}\text { Combination } \\
\text { security }\end{array}$ \\
\hline $\begin{array}{l}\text { External } \\
\text { flexibility }\end{array}$ & $\begin{array}{l}\text { Numerical } \\
\text { flexibility }\end{array}$ & \multicolumn{2}{|c|}{ Version I: Golden Triangle } & & & & \\
\hline \multirow[t]{3}{*}{$\begin{array}{l}\text { Internal } \\
\text { flexibility }\end{array}$} & $\begin{array}{l}\text { Working } \\
\text { flexibility }\end{array}$ & & & \multirow{3}{*}{\multicolumn{4}{|c|}{ Version 2: Centralized Decentralization }} \\
\hline & $\begin{array}{l}\text { Functional } \\
\text { flexibility }\end{array}$ & & & & & & \\
\hline & $\begin{array}{l}\text { Wage } \\
\text { flexibility }\end{array}$ & & & & & & \\
\hline
\end{tabular}

Adapted from Bredgaard et al. 2009; Wilthagen \& Tros, 2004

adverse effects of transitions between jobs and some securities apply only when an employment relationship is in place (Ibsen \& Mailand, 2009). The latter will usually be regulated by collective agreements in Denmark as the coverage rate is approximately $75-80 \%$ of all employees (Larsen et al. 2010).

\section{Version I: The Golden Triangle}

The classic presentation of the Danish flexicurity model is the Golden Triangle (Madsen, 2006) which can be seen as version 1 of flexicurity in the matrix above.

Flexicurity scholars subscribing to the 'Golden Triangle' have stressed how relaxed employment protection legislation and thus high external numerical flexibility is balanced with high spending on active and passive labor market policies which ensure high employment and income security (Bredgaard et al. 2009).

Relaxed employment protection legislation (EPL) should make employers less riskaverse in hiring labor as they can easily shed it again. The restrictions in Denmark are few. Collective agreements at industry level stipulate certain short notice periods for production workers according to seniority, while the Law for Salaried Workers determines notice periods for salaried workers. The latter are substantially longer than for production workers - begging the question if the 'Golden Triangle only applies for blue-collar workers. Other than that there were no regulatory restrictions to redundancies until 2010 when social partners agreed to a modest severance payment for senior workers.

Flexicurity scholars argue that the 'Golden Triangle' has made Danes more attuned to mobility between jobs as they feel secure during transitions due to the comprehensive and generous unemployment benefits system (Bredgaard et al 2009). The main costs of economic restructuring in other words lie with the state and not the individual (Katzenstein, 1987).

Historically, however, trade unions accepted the managerial prerogative at the workplace in return for the right to organize workers and the right to collective bargaining 
as a result of the September Compromise in 1899. Indeed, the system is not a product of design but of historical compromises along the way and the 'Golden Triangle' in its now famous setup did not appear until 1990s when the Social Democratic government introduced novel elements to the active labor market policies (ALMP). The aims of the new policies were on one hand to circumvent the adverse labor supply effects from high benefits on employment and on the other hand to facilitate quick mobility and avoid bottle neck problems in the labor market (Madsen, 2006). The new ALMP regime as such married a social democratic focus on vocational education and training (VET) with neo-liberal focus on 'work-first' through e.g. activation measures.

While not a product of a 'master-design', the combination of flexibility and security is, nonetheless, thought to have contributed to the remarkable labor market performance of Denmark in the 1990s and onwards where unemployment was reduced from $12,4 \%$ to $3,4 \%$ in 1994-2007 (Statistics Denmark 2009) without incurring massive inflation. Some commentators have argued that this policy mix - although not a result of deliberate design - has fostered an institutional complementarity which bridges neo-liberal and social democratic elements based on social compromises between capital, labor and government (Pedersen 2006).

Danish flexicurity scholars have frequently acknowledged, however, that the impressive record cannot solely be explained by the 'Golden Triangle' and that fiscal policies and industrial relations must be considered if we are to understand developments since the 1990s (Ibsen and Mailand 2009; Madsen 2006). In line with this, both van den Berg (2008) and Klindt (2008) have argued that Danish policies during the 1990s to a large extent resemble the Swedish Rehn-Meidner (R-M) model which was presented by two trade union economists at a LO-congress (union confederation for blue-collar workers) in 1951. Klindt (2008) has illustrated the connections of Danish flexicurity policies during the 1990s and onwards with the R-M model in the figure below:

Figure 2: Rehn-Meidner Model adapted to the Danish policies from the 1990s and onwards

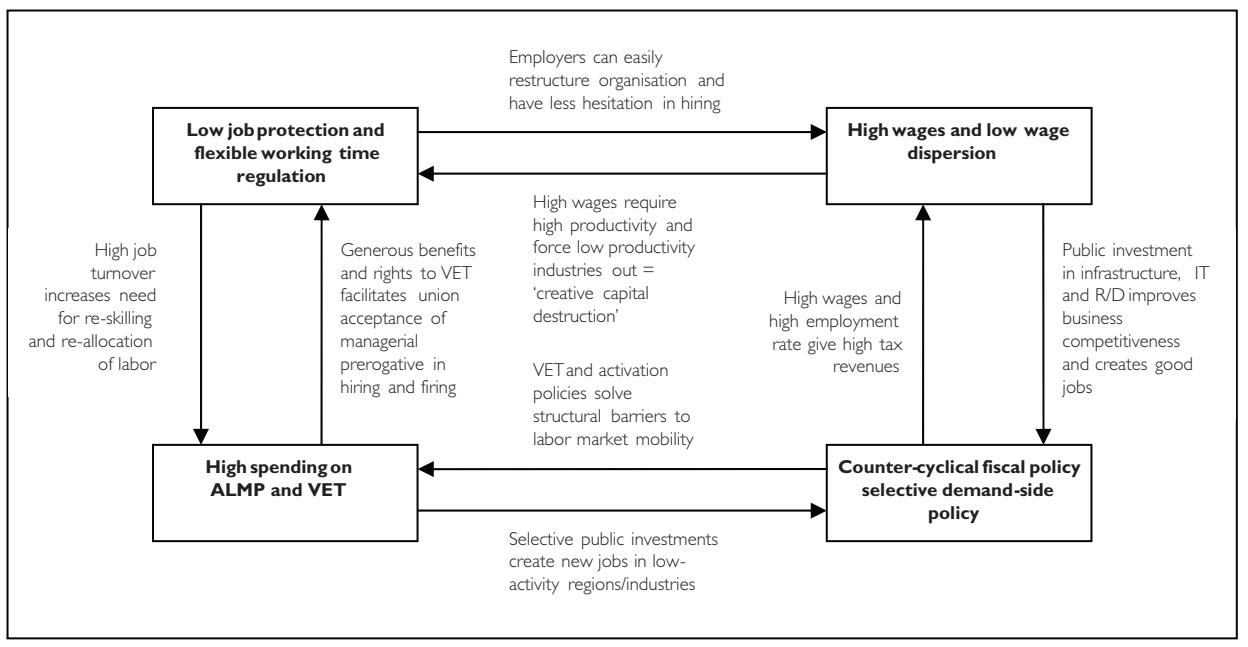

Adapted from Klindt (2008) 
The R-M model - designed for post-war Sweden in the 1950s - entails a policy similar to the Danish flexicurity version 1 aiming at full employment, high economic growth, price stability and fair and egalitarian wages (Erixon, 2008). Contrary to much post-war economic thinking, the policies are not based on Keynesian demand-stimuli as price stability is put at the core of the model through a restrictive fiscal and monetary policy under normal business activity. Instead, fiscal and monetary policies can only be used selectively to counter severe depressive tendencies in the economy. As Klindt (2008) argues, this actually was the policy of Danish governments during the 1990s.

R-M model also prescribes egalitarian wage setting through centralized collective bargaining which ensures equal pay for equal jobs and unequal pay for unequal jobs according to skill levels. The egalitarian wage setting and the restrictive monetary and fiscal policies will moreover squeeze profit margins and force unproductive companies to either go out of business or rationalize, i.e. an element of 'creative destruction'. Conversely, very productive companies are expected to refrain from paying excessive wages due to the centralized wage setting, hereby off-setting inflationary wage-spirals.

R-M and 'Golden Triangle' resemble each other when it comes to the role of mobility and ALMP. R-M envisions that mobility between jobs is essential to keep the aim of full employment and anti-inflation. ALMP such as retraining, vocational, education and relocation grants together with matching actions (primarily public information services) and as noted above targeted demand-oriented policies to increase demand for labor in certain regions, industries and firms shall furthermore facilitate mobility. If wage-setting is not to be the main allocator of labor, then ALMP will (Erixon, 2008; Klindt, 2008). Mobility is - as noted - cushioned by income security in job transitions, i.e. high unemployment benefits, again resembling the 'Golden Triangle' in theory.

\section{Version 2: Centralized Decentralization}

While the similarities between flexicurity and the R-M model pointed out by van den Berg and Klindt seem warranted, there are important differences that reside in version 2 of internal flexicurity as depicted in figure 1: Centralized decentralization ${ }^{1}$ (Due et al. 1993).

As noted, the elements of version 2 are by and large regulated through collective agreements the contents of which have gradually been decentralized to the workplace in a centralized manner. Klindt (2008) notes that this process took place for wages in the 1990s as mandatory wage-rates were turned into minimum levels - albeit at internationally high levels - thus giving some form of in-work income security (Ibsen \& Mailand, 2009). Only approximately $15 \%$ of private sector employment covered by collective agreements have wage levels set in central agreements. The rest have either minimum wage systems or figureless agreements (DA, 2009).

Klindt moreover argues that Danish wage-determination de facto resembles the Swedish ideal for egalitarian wage-setting in the R-M model by following the pattern set by the key bargaining manufacturing sector. However, it is important to note that the flexible wage systems in Denmark - not least for white-collar workers with 
figureless agreements - give considerable wage flexibility that was not envisioned in the R-M model. As a minimum, the abolition of any upper-limit to local wage deals as of 1993 means that high-productivity companies run the risk of inflating wages, but downward wage flexibility is de facto also part of the system as the minimum wage levels are far below the actual wages.

Another essential difference is the considerable decentralization of working time and the equally important elimination of job demarcations in especially manufacturing. These internal forms of flexibility have been successfully pursued by employers during sector level bargaining rounds of the last couple of decades in an exchange for the establishment of pension funds, maternity/parental leave funds and improved VET rights. As such, pension, leave and VET rights/funding comprise the security elements of version 2 - income, combination and employment security, respectively (Ibsen \& Mailand, 2009).

Staying with the flexicurity matrix, version 2 provides high working time flexibility which on top of enhancing productivity also is used to curb labor costs as employers avoid expensive overtime pay. Employees, on the other hand, have greater freedom to organize their working time, thus increasing combination security.

Similarly, functional flexibility has been taken on by DI (Confederation of Danish Industries) through a series of agreement modernizations that eliminate job demarcations and thus feeds into productivity enhancing work re-organization (Kristensen, 2006). The focus on VET by unions should be seen in line with these changes.

The development of centralized decentralization resides not only in minimum levels from sector agreement but also comprise an institutional and cultural reproduction of collective bargaining at the workplace level (Due et al. 1993). Local shop stewards are put in charge of bargaining wage, working time and VET provisions with management in local agreements and they are often highly involved in quasi-managerial decisions involving work organization, VET-plans and thus productivity enhancements (Kristensen, 2006). It follows that decentralized bargaining opens for the possibility, that flexicurity balances are determined by local bargaining parties and the institutions framing local bargaining (Nergaard et al. 2009). This in turn puts pressure on local parties to reach innovative agreements that take various interests into account in a balanced way (Regalia 2006).

The activities of shop stewards - both bargaining and cooperation - are however carried out according to a partnership approach with management in which there is no right to industrial action. According to the Basic Agreement between the labor and employer confederations, LO and DA, and the Law on Mediation, the right to industrial action only applies for renewal or establishment of collective agreements at the sector level, not for local bargaining when the company is already covered by a collective agreement.

In sum, the flexicurity concept - in the multifaceted sense used here - forces us to look at the host of interplays between flexibility and security inherent in the Danish labor market regulation. As a corollary, employers and shop stewards have a panacea of options in how they chose to react to economic forces demanding restructuring. Some in line with in the 'Golden Triangle' - pertain to external numerical flexibility, i.e. shedding labor with cost of restructuring to a large extent being covered by the state through unemployment benefits and ALPM. Others will pursue internal forms of flexibility with cost of restructuring being borne in the main by the individual worker. 
Bridging the two versions of flexicurity is the use of subsidized work share and retraining options in which the state bears the larger part of costs while the individual workers and the employer share the costs until the economic conditions change for the better. Shop stewards are involved in negotiating the arrangements that can be used to forestall redundancies but only for a limited period of 13 weeks ${ }^{2}$ using the unemployment benefits to top-up reduced earnings due to reduced working time.

\section{Expectations to practice of social partners during crisis}

Following Version 1 of 'Golden Triangle' and its Rehn-Meidner analogy, social partners at company level can be expected to react to an impetus for restructuring in a number of ways, thus revealing the underlying social compromises at company level.

If Version 1 flexicurity rests on stable compromises, we would expect company level practices during an economic crisis to accord with this flexicurity logic:

1. The main method of restructuring is through external numerical flexibility, i.e. redundancies, as opposed to wage and working time flexibility.

2. Continued union acceptance of few restrictions and thus low costs of hiring and firing.

3. Unions will refrain from concessionary bargaining on terms and conditions, especially wages and working time. As noted above, cost of structural adjustment in the economy lies with the state.

4. We would expect unions to adhere to the peace obligation during collective agreements and not resort to illegal strikes against proposed redundancies.

Version 2 flexicurity, however, invites to more varied responses to the impetus for restructuring involving internal forms of flexibility that may complement (5\& $\&$ ) or go counter to the above mentioned practices (6):

5. Functional flexibility and productivity enhancing measures are used to increase competitiveness, save orders and jobs.

6. To cut labor costs and save jobs, unions make concessions through wage-freezes or even wage cuts.

7. Working time flexibility (subsidized or not) is used to cut labor costs.

Looking at the specific actions of social partners at the company level should reveal whether the present crisis as such has had any impact on the types of responses to restructuring, and the case studies will therefore show if practice and thus the robustness of compromises depend on the specific external pressures due to the crisis - and not on the logic of version 1 flexicurity. Similarly, according to Version 2, we would expect unions to have a much more pragmatic bargaining strategy including concession bargaining when attempting to safeguard jobs (Léonard 2004). 
Finally, there is the possibility that unions are in such dire circumstances that they will depart from the compromises inherent in both versions 1 and 2 and resort to what we can call anti-flexicurity behavior to safeguard jobs:

8. Unions use illegal industrial action to combat plans of redundancies.

9. Unions claim stricter job protection regulation.

\section{Methods and Data}

The article brings together two analyses at company level that combined give an overview of the practice of social partners before and during the present crisis.

The analysis at company level is based on two rounds of qualitative semi-structured interviews before (in 2007) and during the current crisis (in 2009) with shop stewards in three major Danish metalworking companies - in the following called A, B and C. This was combined with a few clarifying interviews with managers in one company (A) and background interviews with union officials on union strategies towards restructuring. In total, 16 persons were interviewed. The semi-structured interviews were focused around four kinds of responses to redundancies: Employer practice of restructuring employment, demands for stricter job protection regulation and redundancy terms, concessionary bargaining on terms and conditions of employment and finally industrial action against redundancies. These categories were used to code the interview transcripts in NVIVO.

Interview data were combined with documentary material on employment figures and redundancy procedures which was given by informants or obtained through company headquarters.

All companies had experienced redundancies but for different reasons. In 2007, redundancies were mainly motivated by relocation of production to other countries, while in 2009 redundancies were more directly linked to negative economic circumstances. Since, considerable restructuring of employment had occurred both in 2007 and 2009 it is possible to compare practice of social partners during restructuring and thus the flexicurity compromises for both periods.

\section{Compromises before and during the crisis}

Before proceeding to the actual analyses it is instructive to get an idea - albeit rough and preliminary - about the kind of pressure the proposed flexicurity compromises came under when the present crisis hit Denmark. Although an account of the possible reasons for the specific impact of the crisis on the Danish economy is far beyond the scope of this article, it seems, nonetheless, well established that 1) Denmark was in a very favorable economic situation at the outset of the crisis 2) Denmark was one of the first European countries to be hit; 3 ) the negative impacts have been relatively more severe on key socioeconomic indicators than in other Northern-European countries and 4) the bounce back of the Danish economy (in terms of growth) has been somewhat slower than in other countries (Finansministeriet 2009).

It could be argued that the economy in Denmark was already slowing down in 2007 with modest real GDP growth rates. However, the 2009 figures in table 1 reveals the overall magnitude of the crisis with a $-4,9 \%$ drop in real GDP (the EU-27 dropped from 2,9\% 
Table I GDP-growth and unemployment rates before and during the crisis

\begin{tabular}{lcccc}
\hline & \multicolumn{2}{c}{2007 (yearly averages) } & \multicolumn{2}{c}{2009 (yearly averages) } \\
\hline & Denmark & EU-27 & Denmark & EU-27 \\
\hline Real GDP growth rate & 1,7 & 2,9 & $-4,9$ & $-4,2$ \\
\hline Unemployment rate (ILO-def.) & 3,8 & 7,1 & 6,0 & 8,9 \\
\hline
\end{tabular}

Source: Eurostat, 2010

to $-4,2 \%)$. What is moreover remarkable for Denmark is the rapid rise in unemployment and not so much the level of unemployment which in 2009 was still relatively low by European standards as can also be seen in the table. When comparing to for example Germany and Sweden, Danish unemployment rates have increased sharply from $4,1 \%$ in the last month of 2008 when recession hit Denmark to 7,2 the same time next year. In Germany and Sweden, the increase in this period has been from 7,1 \% to 7,6 \% and from $7,0 \%$ to $8,9 \%$, respectively (Eurostat 2010). Note that these figures should be viewed with some caution as many German workers were placed on work-share schemes (Andersen 2010).

While it might seem natural that Denmark, with record-breaking low unemployment rates in the second quarter of 2008 , has experienced more rapid increases in unemployment, the parallel sharp decline in Danish employment justifies some concern. According to a recent analysis, employment has fallen by $4,5 \%$ from the $3^{\text {rd }}$ quarter 2008 to $3^{\text {rd }}$ quarter 2009. Thus, in this period some 104.200 full time employed have exited employment, and since "only" 59.200 of these are registered as unemployed this means that 45.000 have effectively left the labor market all together (Arbejderbevægelsens Erhvervsråd 2009).

As in other countries, unemployment has hit blue-collar (skilled and unskilled) workers in construction (business cycle sensitive) and manufacturing (export-oriented) first and hardest. As an indication of how employment in metalworking was affected, table 2 shows unemployment rates according to union membership and thus occupational groups, in 2008 and 2009.

Table 2 Unemployment rates according to union/occupation in manufacturing

\begin{tabular}{lcc}
\hline & December 2008 & December $^{3} 2009$ \\
\hline I. 3F - Unskilled workers & 5,2 & I0, I \\
\hline 2. Dansk Metal - Skilled workers & 2,0 & 4,0 \\
\hline 3. HK - Salaried workers/Clerks & 2,2 & 7,7 \\
\hline 4. TL - Technicians & 2,5 & 7,4 \\
\hline 5. TIB - Craftsmen & 5,2 & 10,8 \\
\hline 6. EL - Electricians & 0,9 & 5,2 \\
\hline
\end{tabular}

Sources: CO-Industri 2010 
In Danish manufacturing, an approximated total of 66.000 jobs were lost since the recession hit in the second quarter of 2008 (Arbejderbevægelsens Erhvervsråd 2010), reflecting a drop in production levels from late 2008 to late 2009 of $22,6 \%$. As can be seen in table 2, only the skilled workers kept their buoyancy, but even these groups suffered important redundancies and doubled their unemployment rate. Unemployment figures from 3F (United Federation of Danish Workers) furthermore showed that unskilled manufacturing union members had similar unemployment rates as their peers in construction around $12 \%$ into 2010 (www.3f.dk).

This considerable drop in production levels also had a discernable effect on local wage developments ${ }^{4}$. In 2007, Danish manufacturing wages grew by 4,6\% while in 2009 the increase had dropped to 3,8 \% which is still relatively high compared to other European countries (Dansk Arbejdsgiverforening 2010). The wage-growth reflects the rather generous wage agreements struck before the crisis hit. DI, however, reported that $25 \%$ of member companies negotiated wage freezes in local wage negotiations for 2009 (DI 2009).

In a similar vein, work share arrangements were put in place touching some 30.000 Danish employees between January and September 2009 - most of these were in manufacturing (Andersen, 2010).

\section{Strained compromises at company level?}

In order to give indications of what is happening to the flexicurity compromises at company level this section analyses two rounds of company level restructuring in 2007 and 2009 in three major metalworking companies. In the following each company is given a letter: A, B, C.

All three companies were in 2007 relatively large companies for Danish standards, producing both components and assembling them for upscale product markets. This, however, changed dramatically for company C, because the production of components was being relocated. This was less the case in A and B which in despite of relocation retained production of components in Denmark. The results are summarized in the table below.

\section{7}

Employer practices of restructuring employment evidently vary somewhat depending on the business cycles, but as already noticed; employment restructuring was needed in both periods for all three companies - albeit at different levels.

In A, some 600-700 jobs had been relocated during the period of 2001-2007 and the company employed approx. 22.000 worldwide in 2007. In B the actual number of relocated jobs was unknown to the informant but the company employed approx. 16.000 worldwide in 2007. In 2007 the scale of relocation in companies A and B was at a level where comprehensive schemes for in-house redeployment, normal labor turnover and early retirement plans could be used to alleviate some of the negative employment effects of relocation, hereby reducing the number of redundancies. These internal employment restructurings demanded high functional flexibility on 


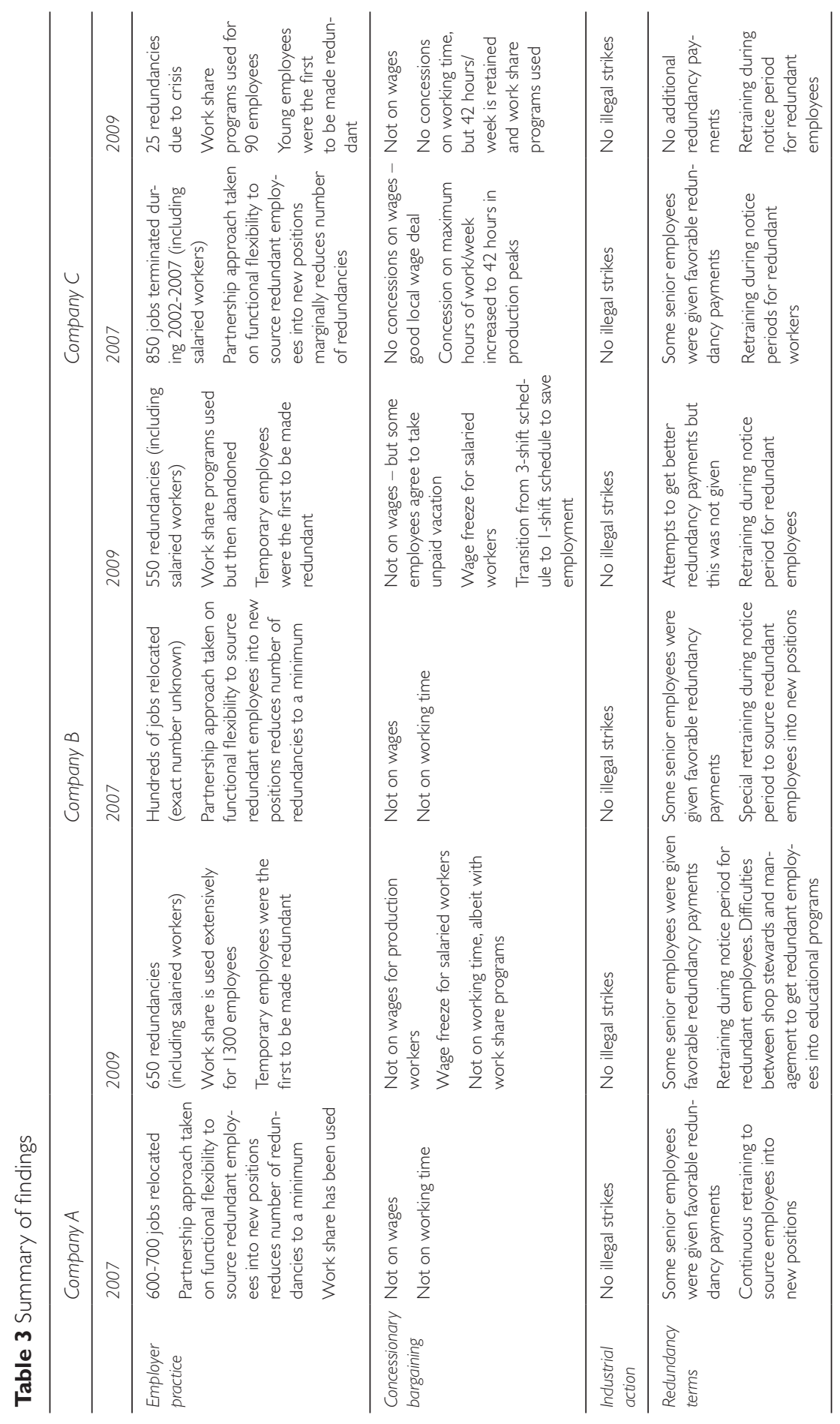


the part of the employees who often needed retraining to perform new tasks in the production line. In total, there were very few forced redundancies as a result of the relocations, which also reflected constant new orders and new production lines in $\mathrm{A}$ and $\mathrm{B}$. This was less so the case in company $\mathrm{C}$ which was also troubled by reductions in market shares. During the period of 2002-2007 the plant in question had gone from employing 1.200 workers to 350 . Thus the scope of restructuring meant that redundancies were needed when possibilities for redeployment and early retirement had been exhausted which in turn had a significant impact on the choices unions were faced with.

Concessionary bargaining on wages was nonetheless absent in all three companies despite the varying pressures on employment. Local wage bargaining remained intact with substantial supplements negotiated each year. In accordance, attempts by management to use the threat of relocation to pressure wages were thwarted by shop stewards even in C. The general union view was to remain firm in local bargaining and not enter into international labor cost competition. Resistance was also facilitated by crosscompany communication among shop stewards to coordinate wage demands vis-à-vis management. Despite relocations, the three companies thus followed suit on the general wage increases in Denmark during the economic boom of 2007. More importantly for our purposes, the 2007 answers also reflected a high feeling of employment security and income security due to the general employment situation and the active and passive labor market policies in the flexicurity version 1.

Nevertheless, $\mathrm{C}$ did negotiate a new deal on working time which increased the weekly average working time to 42 hours during peaks in production. This was done in a mutual attempt to improve productivity as the factories had been falling behind. According to the shop stewards at C, the threat of relocation somewhat pushed shop stewards into this agreement, but the add-on wage connected to a $42 \mathrm{~h} /$ week also helped.

Despite the peace obligation, trade unions have sometimes accepted the collective fine to unions given for illegal industrial action in order to reverse managerial decisions or to express discontent in general. This is reflected in work stoppages in breach of the collective agreements of which there were 768 in 2007 (69.094,9 work days lost) - a relatively high number due to the collective bargaining round of that year, which always sparks illegal strikes.

However, this was not the case in any of the three companies as shop stewards viewed the measure as futile and poor compared to dialogue about how to counter the negative consequences of restructuring. Some employees in company A had attempted to mobilize work stoppage in protest with management, but this was quickly thwarted by shop stewards who reminded their colleagues of the peace obligation. Indeed, shop stewards are obliged to do so according to the Basic Agreement. Similar employee discontent had surfaced in B and $\mathrm{C}$, but in both cases without any direct attempts to stop work.

Interviews in 2007 revealed that - beyond their legal obligations - shop stewards preferred a partnership approach to handling redundancies and made reference to the high unemployment insurance benefits but also to the possibilities of alternative employment either in-house or in the region. Industrial action as an expression of frustration and discontent and as strategy to reverse decisions by management was therefore irrelevant when shop stewards weighed their options. 
Turning to redundancy terms, the scope for action at company level might seem limited at first sight as noted above. Nonetheless, shop stewards are free to negotiate local agreements on the terms of redundancies, including redundancy payments, longer notice periods and extra training for redundant workers during the notice period. Arguably, redundancy payments will directly infringe upon the external numerical flexibility as it increases the cost of firing for companies, while extra training has a more indirect impact since courses typically involves public subsidies or funds from the Educational Funds set up in 2007. Rather, therefore, extra training would be a cost for companies as workers are taken out of work during the notice period - this of course depending on the actual demand for the labor of these workers.

Regarding redundancy payments, interviews in 2007 reflected the different pressures on employment. In company A no serious attempts were made by shop stewards to get enhanced redundancy payments as the focus was squarely set on moving employees into new positions within the company, or - as a last port of call - into other companies in the region.

The picture was different in company B and C where senior production workers had been given redundancy payments when relocated jobs could not be absorbed into new positions. Here, shop stewards were successfully engaged in negotiating favorable redundancy payments to senior production workers - similar to a "Golden Handshake" for long faithful service to the company. In a situation where work morale was under heavy pressure from growing job insecurity, management was not unrelenting in conceding to this.

Regarding extra training the companies differed slightly according to their specific relocation procedures. In company A, training was often not part of the relocation process as employees were busy co-managing the move of jobs abroad. Indeed, shop stewards would then negotiate six months longer notice periods for redundant workers to alleviate the risk of there being no job opening after the relocation process was done. According to the informant in A, training in connection to relocation should rather be seen as a continuous part of constant moving of employees into new positions, underlining the need for high functional flexibility of workers. In company B and C, shop stewards would make training available for workers - either for in-house re-employment (in B) or to prepare workers for job-hunting when the notice period was over (in C). In company $\mathrm{C}$, shop stewards and management formalized procedures for training connected to redundancies in a local agreement whereby any disagreements on the shop floor could be swept away.

\section{9}

Employer practice of restructuring employment shifted between the three companies in 2009 as companies A and B came under severe pressure to reduce labor costs through various means in order to curb the negative effects of declining orders. Company $\mathrm{C}$ on the other hand was less under pressure as the massive restructuring process had already been under way and it needed to make fewer cuts in staff which evidently affected the dynamics during the crisis. Nonetheless, all three companies were hit by redundancies.

As in 2007, the initial actions to curb negative employment effects were centered on redeployment of staff and early retirement which for the former meant higher demands 
for functional flexibility. However, the scale of falling production orders due to a market in recession soon called for more drastic measures.

In Denmark management and shop stewards can agree to transfer large shares of production workers to state subsidized work share programs in which working time is reduced for either the entire company or an entire department. The employee will be compensated up to the capped unemployment insurance benefit level at approx. DKK 15.500 (€ 2.010) a month. The program can be used for up to 13 weeks during 12 months with possibility for further extension.

In company A, some 1.300 workers (skilled and unskilled) were touched by such a work share scheme, during which they could not be made redundant. This did not, however, relieve the pressure to lay off workers, and at the time of the interview (October 2009) approximately 650 workers had been given notice of redundancy in two major rounds. In the first round, some 200 workers, many of which were temporary workers and unskilled, were made redundant. This was followed by a second round where many salaried workers (roughly 400) and some production workers (50) who were not in work share schemes were made redundant. Globally, the company now employed 17.000 persons in 2009 compared to approximately 18.000 in 2008.

In company $\mathrm{B}$, however, efforts to curb redundancies through work share, was abandoned after a few weeks, when the severity of the crisis was realized. Layoff of workers then started with relocation to Mexico of approximately 50 jobs. This was followed by several notified rounds of redundancies of between $30-80$ jobs. In total, some 400 production workers were made redundant at the plant in question adding to the layoff of 150 salaried workers. At the time of the interview (October 2009), production staff had been reduced from 1.300 workers to approximately 900 in the plant. Globally, employment in the company had been reduced by $20 \%$ and was now at approximately 26.000 employees.

In company $\mathrm{C}$ - as noted above - employment had already been significantly reduced during recent years bringing the required labor "slimming" to a minimum. In total, only 25 employees had been made redundant while 90 had been put on work share to safeguard their jobs. The company had now been split up so figures mentioned here exclusively refer to the plant in question.

Did the rather bleak situation translate into concessionary bargaining? Interviews suggest that the approach on local bargaining for production workers followed the line of 2007 despite the much heavier pressures on employment. The picture is slightly different for salaried workers.

In company A, no concessions were made on wages as shop stewards were aiming for increases as usual - albeit with lower expectations than in 2007. Cuts in wages or wage freezes were out of the question according to the interviews. Similarly, no new working time arrangements had been introduced - apart from the work share program.

In company $\mathrm{B}$, management suggested to their production workers to forgo already agreed wage increases to preserve employment, but this was rejected by shop stewards on the grounds that cuts in costs should be found elsewhere. Production workers had suffered enough and the general feeling was that wage concessions would not save threatened jobs anyway. Indirectly, salaried workers were giving concessions as they individually agreed to spend unpaid vacation - a de facto wage concession. This was done without shop stewards' consent. Management in addition to this dictated a wage-freeze for salaried workers who to a larger degree bargain individually on wage supplements. 
Concerning working time, production workers in company B had shifted from a 3-shift schedule to only one shift, reflecting reduction in orders. This meant a de facto wage reduction as shift premiums were forgone.

In company $\mathrm{C}$, local wage bargaining was not affected by the crisis for production workers. Shop stewards resisted calls - albeit feeble - by management for concessions. As in company B, the case was different for salaried workers who agreed or rather accepted a wage-freeze in face of falling revenue for the company. On working time, no further concessions were made as the 42 hour/week in peaks was maintained.

Due to the increased pressure on employment in the three companies, it might be expected that shop stewards and union members would change their stance on industrial action to counter redundancies. As noted above, while the peace obligation makes it punishable to strike when collective agreements are in force, industrial actions have been carried out in the past to show discontent with managerial decisions. In contrast to the situation in 2007 when frustration was curbed by arguments about high income security and alternative employment possibilities, shop stewards' attitude towards management had changed in a negative direction - a consequence of the often stressful task of managing massive restructuring.

Interviewees in all three companies, nonetheless, reported an unchanged approach to work stoppages as this was still considered a futile strategy vis-à-vis the proposed redundancies. It would seem that the partnership approach to restructuring had been maintained through the crisis despite the cooling off in union-management relationships.

Turning to redundancy terms, the shop stewards in company A were successful in getting extra redundancy payments for senior workers with an additional aim of mitigating the negative sentiments in the workforce. In B, the attempt was unsuccessful and redundant workers were left with standard notice periods. Shop stewards gave no immediate reasons for why attempts failed. In company $\mathrm{C}$, there were no attempts as the workers who were made redundant typically had low seniority with the company. This point underlines that extra redundancy payments are usually given to senior employees.

While practice on redundancy payments differed, there was a common strategy in all companies to provide extra training during notice periods as an instrument to upgrade the skills of primarily unskilled production workers. However, any relevant funds - either public or from the educational funds of social partners - had been exhausted to satisfy the massive demand during the crisis.

In company A, management was hesitant to use notice periods for training and shop stewards had to fight to get permissions. Management in company B had been more proactive despite the substantial work needed to set up courses. However, the interviewees in A and B with regret noted that courses served as a "parking space" for redundant workers during their notice period rather than actually improving their skills. In C, the company's own educational funds ran out due to the massive need. Here, shop stewards were successful in putting redundant workers on public courses during the notice periods thereby enabling workers to receive full pay during the course.

\section{Discussion of findings}

Admittedly, the findings reported here (see the summary table above) are not representative of the metalworking sector as a whole, let alone of the entire Danish labor market. 
In order to broaden the perspective somewhat the above findings are therefore discussed in relation to general industrial relations developments in 2007 and 2009/10. This will give a better idea of the relative robustness of flexicurity compromises during the two periods and show the interconnections between local and central levels.

At a glance the two rounds of interviews do show a shift in practice on some of the dimensions which backs the overall hypothesis that practice at company level reflects the immediate employment situation in each company. However, there was also evidence of stable practice despite the different pressures stemming from changed economic circumstances. The most important changes were in 1) employer practice, 2) concessionary bargaining to save employment and 3) redundancy terms.

Concerning the first, clearly the dramatic drop in labor demand changed the practice of in-house re-employment in A and B to heavier reliance on external numerical flexibility. This does however not contradict the flexicurity compromise - on the contrary since flexible hiring and firing is one of the key pillars in the 'Golden Triangle'. Redundancies were, however, combined with extensive use of work share in company A and C, while this was abandoned in B where external numerical flexibility was deemed unavoidable. This shows that managements in Denmark use a host of practices - both internal and external - to adjust the labor force to demand. Seen in isolation this does somewhat contradict the Version 1 flexicurity hypothesis that external numerical flexibility is the preferred option. However, when compared for example to German use of short-time working - which was approximately 1,4 million workers in June 2009 out of 43,6 millions economically active (approx. 3,2 \%) - the Danish take-up of the option - approx. 30.000 workers between January and September 2009 out of 2,8 millions economically active (approx. 1 \%) seems rather modest given comparable drops in production levels in the two countries. Note also that the maximum period in Germany is up to 24 months compared to the maximum of 26 weeks in Denmark. This is perhaps an indication of the different practice of external versus internal flexibility in the two countries (Andersen, 2010) and thus gives support to practices according to Version 1 flexicurity compromises.

Concerning the second change - concessionary bargaining - the picture is also mixed, albeit with some identical patterns. Firstly, production workers retained the bargaining strategy as usual despite managerial pressures to cut wages. This was resisted with reference to the burdens this group had already taken through massive and earlier redundancies. Conversely, salaried workers accepted wage freezes more or less voluntarily to safeguard jobs, reflecting their longer notice periods but perhaps more importantly their relatively more individualized pay setting. Indeed, one would expect that the two occupational groups' attitudes to concessionary bargaining differ. It is also worth remembering how decentralization also involves a reproduction of centralized bargaining at workplace level. Here, the shop stewards of production workers will be more adamant to downward wage flexibility while individual salaried workers will be on their own devices vis-à-vis management. The cases thus underline the impact of local collective representation during times of restructuring.

A second variant of concessionary bargaining includes the work share schemes which can be viewed as a subsidized concession on working time, albeit with income security. Finally, company B changed from 3-shifts to 1 shift working to safeguard jobs which actually means a reduction in earnings due to loss of shift premiums.

When looking at aggregate figures for local wage bargaining one finds that approximately $25 \%$ of DI-member companies (the main employer confederation) negotiated 
wage freezes in local wage negotiations in 2009 . However, the average yearly wage increases in private sector employment only dropped modestly between the two periods as noted above. As such, the average increases are still quite high relative to other countries' wage increases, indicating a relative stickiness in Danish wages, perhaps due to already agreed increases together with local wage bargaining resilience.

The level of wage increases in sector level bargaining changed considerably when social partners in the manufacturing industry agreed to very modest wage increases in the 2010 two-year agreement that presumably only barely will maintain real wages in the subsequent local wage agreements. However, these modest wage levels can hardly be seen as concessionary bargaining but rather as a 'normal' adjustment to the bargaining powers of the trade unions vis-à-vis employers during times of high unemployment. To sum up, the third flexicurity compromise about concessionary bargaining seems to have been partly strained at company level as some groups have accepted either direct or indirect concessions on wages and working time. Collective agreements allow this as part of 'centralized decentralization' in framework provisions on wage and working time and the actual balance is left to shop stewards and their bargaining powers locally.

Finally, practice of redundancy terms also seemed to have been affected by the changed circumstances. Although the strategies of getting enhanced redundancy payments and extra training was present in both periods, shop stewards were much more involved in these endeavors in 2009 due to the increasing number of redundancies. Both in a direct way (redundancy payments) and indirectly (extra training) this practice increases the cost of external numerical flexibility albeit in varying degrees. However, in many instances extra training can be subsidized and redundancy payments were almost exclusively given to senior employees as a "Golden Handshake" for long service. Furthermore, in company B and C extra redundancy payments were not conceded by management despite union efforts. Nonetheless, the union practices in this respect do go somewhat counter versions 1 and 2 .

As noted in the above section, notice periods for production workers are typically stipulated in collective agreements at industry level. It is therefore instructive to mention the additional redundancy payment for senior employees, that was agreed upon in the 2010 agreements of manufacturing - a direct response to calls from union members and shop stewards demanding more security as a consequence of the crisis. The provision tops up unemployment benefits thereby securing redundant workers a replacement rate of $85 \%$ the first month for workers with three years employment; two months for employees with six years employment and three months for employees with eight years employment.

Arguably, this innovation touches upon the external numerical flexibility since costs of firing are internalized in the companies - albeit in a rather modest way. However, comments by trade union officials indicate aims to enhance this payment should parliament fail to enhance the statutory unemployment benefits which at the moment stand at a replacement rate of approximately 50-55\% for an average Danish skilled worker. This indicates that income security for the time being is perceived as too low which could jeopardize union acceptance of permissive hiring and firing and thus the 'Golden Triangle' flexicurity compromise. Alternatively, the provision could be seen as an innovative way to ensure income security in times of political stalemate.

What has not changed between the periods is the reluctance to use industrial action to prevent redundancies. While not surprising in general because of the peace obliga- 
tion during collective agreements, general figures confirm a considerable drop in illegal strikes during recent years. Overall, 2009 saw the lowest figures of company level strikes in breach of the collective agreement since reporting started in 1991. As such, the partnership approach prevails despite changing economic circumstances - indeed it can be argued that unions will be more appeasing during economic slumps due to reduced bargaining power (Hibbs Jr. 1976). Indeed, the 2010 collective bargaining round was concluded with an appeasing yes in the union ballot despite very modest wage increases.

It seems clear that the proposed compromises of version 1 are indeed strained both at company and national level as social partners try to steer clear of the crisis. Nonetheless, changes are not uniform but contingent upon the immediate issues at hand for management and shop stewards. As such, the responses in the three companies are piecemeal and pragmatic according to the various possible practices in both versions 1 and 2 flexicurity.

\section{Conclusion}

The article tries to identify four so-called flexicurity compromises between social partners hereby linking the "Golden Triangle" to industrial relations. These were 1) a managerial preference for external numerical flexibility when restructuring the workforce, 2) union acceptance of ease of hiring and firing, 3) unions refraining from concessionary bargaining and 4) unions refraining from industrial action to counter restructuring and instead choosing a partnership approach.

However, the article also argued that flexicurity in Denmark also includes internal forms of flexibility and security that are equally important when employers and shop stewards have to respond to the impetus of restructuring. These include 5) functional flexibility, 6) wage flexibility and 7) working time flexibility.

By comparing two rounds of case-based interviews in three metalworking companies in 2007 and 2009, respectively, it was shown that practice has indeed changed albeit modestly - due to worsened economic circumstances. The interviews showed that the hypothesized preference for external numerical flexibility is perhaps too crude as employers use different ways to restructure the workforce - this applies in both rounds. However, a comparison of aggregate figures of work share programs between Denmark and Germany does indicate a Danish preference for external flexibility.

The 2009 interviews revealed that the severity of redundancies did not change union practice on concessionary bargaining on wages for production workers to save jobs. Salaried workers, however, did agree to wage freezes. Nonetheless, shop stewards were willing to look at working time - both through work share programs but also working time reductions which bore with them de facto reductions in income.

In order to increase employability of redundant workers, shop stewards have pushed for extra training during redundancies to a lot larger degree in 2009 than in 2007. Moreover, they have tried to negotiate favorable redundancy payments for senior employees but with varying success due to managerial reluctance in one of the three companies. It is unclear how much this raises the costs of firing for employers. The change in union attitude to redundancies and income security is underlined by the recent agreement to introduce redundancy payments for senior employees in the manufacturing collective agreements. 
Conversely, there has been no change in the rejection of industrial action as a means to avoid redundancies. Indeed, general levels of industrial action during collective agreements have dropped in the period.

In conclusion, it seems that flexicurity compromises of the 'Golden Triangle' have indeed been strained by the economic crisis. Moreover, practice varies across companies which somewhat confirms the hypothesis of varied responses across versions 1 and 2 . This shows how compromises between social partners are in constant flux and contingent upon the immediate employment at hand which in turn alerts to the dangers of building analytical models based on relatively short periods of stability.

The 'Golden Triangle' - while definitely still very relevant - seems in need of complementary concepts which this article has tried to introduce with 'centralized decentralization' - a concept that directs our attention to forms of flexibility and security belonging to industrial relations regulation and practice at both sector and company level. Using these complementary versions of flexicurity, responses to restructuring can hopefully be approached in a more nuanced manner.

Cross-country comparison may, nonetheless, reveal that Danish restructuring practices are relatively persistent despite the above mentioned signs of changes. More research into these country-specific differences during times of change might further our understanding of the interrelationships between labor market models and industrial relations practice.

\section{References}

Andersen, S. K. (2010) Tackling Job-losses - Varieties of European Responses, Article presented at 4'th EU-China High Level Roundtable on Social Security.

Arbejderbevægelsens Erhvervsråd (2009) Beskeftigelsen falder dobbelt så meget som arbejdsløsheden stiger, Arbejderbevægelsens Erhvervsråd, Copenhagen.

Bredgaard, T., Larsen, F., Madsen, P. K., \& Rasmussen, S. (2009) Flexicurity på dansk, CARMA, Aalborg Universitet, Aalborg, 2.

Due, J., Madsen, J. S., \& Strøby Jensen, C. (1993) Den Danske Model: En Historisk Sociologisk Analyse af det Kollektive Aftalesystem København, Jurist- og Økonomforbundets Forlag.

CO-Industri (2010) Årsrapport 2009, CO-Industri, København.

Erixon, L. (2008) The Rehn-Meidner model in Sweden: its rise, challenges and survival, Stockholm University.

Eurostat (2010) Harmonised unemployment rate by gender - total - [teilm020], Eurostat. 2010. Ref Type: Online Source

Finansministeriet (2009) Økonomisk Redegørelse, Finansministeriet, Copenhagen.

Hibbs Jr., D. A. (1976) Industrial Conflict in Advanced Industrial Societies. The American Political Science Review, 70(4): 1033-1058.

Ibsen, C. L. \& Mailand, M. (2009) Flexicurity and Collective Bargaining - Balancing acts across sectors and countries, FAOS, University of Copenhagen, Copenhagen.

Katzenstein, P. J. (1985) Small States in World Markets: Industrial Policy in Europe, Ithaca, Cornell University Press.

Klindt, M. P. (2008) 'Arbejdsmarkedspolitik og institutionel komplementaritet' Samfundsøkonomen, Nr. 6, December: 26-31.

Kristensen, P. H. (2006) 'The Danish Business System transforming towards the New Economy', In National Identity and the Varieties of Capitalism, J. L. Campbell, J. A. Hall, \& O. K. Pedersen, eds., Copenhagen: DJØF Publishing, pp. 295-320. 
Larsen, T. P.; Navrbjerg, S. E. \& Johansen, M. M. (2010) Tillidsreprcesentanten og arbejdspladsen, Rapport 1, LO, København.

Léonard, E. (2004) Négociations sur l'emploi en Europe: Compromis et enjeux. Relations Industrielles, 59(3): 545-568.

Madsen, P. K. (2005) 'The Danish Road to 'Flexicurity': Where are we, and how did we get there?' in Bredgaard, Thomas and Flemming Larsen (eds.) Employment policy from different angles, Copenhagen: DJØF Publishing, 269-291.

Mailand, M. (2009) Coalitions and the Decisions Making Process of the Common Flexicurity Principles. FAOS, Copenhagen.

Nergaard, K., Dølvik, J. E., Marginson, P., Díaz, J. A., \& Bechter, B. (2009) Engaging with Variable Pay: A Comparative Study of the Metal Industry, European Journal of Industrial Relations, 15(2): 125-146.

Olson, M. (1965) The Logic of Collective Action: Public Goods and the Theory of Groups Massachusetts, Harvard University Press.

Regalia, I. (2006) 'What regulation for the new forms of employment?' In Regalia, ed. Regulating new form of employment: local experiments and social innovation, New York: Routledge, pp. 230-264.

Statistics Denmark (2009). AARD: Ledige i procent af arbejdsstyrken efter område og køn (år) (AFSLUTTET). 2009. Copenhagen, Statistics Denmark. Ref Type: Online Source

Tangian, A. (2010) Not for bad weather: flexicurity challenged by the crisis, ETUI Policy Brief, Issue 3, Brussels.

Traxler, F. (1995) 'Farewell to labor market associations? Organised versus disorganised decentralisation as a map for industrial relations," In C. Crouch \& F. Traxler (eds) Organised Industrial Relations in Europe: What Future? Avebury: Aldershot, 1-17.

van den Berg, A. (2008) Flexicurity: Theory, Practice or Rhetoric? Article presented at CARMA Conference 2008. Ref Type: Unpublished Work

Wilthagen, T. \& Tros, F. (2004) 'The concept of 'flexicurity': A new approach to regulating employment and labor markets. Transfer, 10(2): 166-187.

\section{End note}

${ }^{1}$ Traxler (1995) has termed the process 'controlled decentralization' to indicate how sector level agreements remain in place to work as frame work agreements while the actual setting of primarily wages and working time are determined at the workplace but within the frames set at sector level.

${ }^{2}$ On acceptance of local employment councils and social partners the period can be extended for an additional 13 weeks.

${ }^{3}$ Figures are based on the last quarter of 2009 while the unemployment was still on the rise. As mentioned below the unemployment rate for $3 \mathrm{~F}$ union members in construction and manufacturing was as high as $12 \%$ in the beginning of 2010 .

${ }^{4}$ Increases are measured as the change - in percent - from last year wage level. 